\title{
Foreword $^{1}$
}

\author{
Theresa Biberauer \\ Department of Theoretical and Applied Linguistics \\ University of Cambridge \\ England \\ and \\ Department of General Linguistics \\ Stellenbosch University \\ South Africa \\ E-mail: mtb23@cam.ac.uk
}

\section{Background: Hans den Besten's academic legacy}

Hans den Besten (1948-2010) was one of those rare phenomena in modern Linguistics: someone who not only made seminal contributions to more than one sub-field within the discipline, but who also made them in areas that are very often assumed to require very different - not to say entirely incompatible! - ways of thinking: Chomskyan generative linguistics and Afrikaans (socio)historical linguistics. Ironically, though perhaps not so surprisingly, given the status of Afrikaans historical linguistics at the time, I first encountered the name Hans den Besten in the former context. Wanting to know more about the formal side of Verb Second (V2), which had been mentioned in a language acquisition lecture I attended in 1996, I discovered that den Besten (1977/1983) was literally the starting point for all subsequent generative work on V2. The extent to which this is still true today, nearly 40 years after Hans's ideas were first published, is immediately evident if one consults what is currently the most upto-date overview of the topic, Holmberg (2015). Den Besten (1977/1983) - in which it was first proposed that V2 verb-fronting must be connected to the structural domain associated with complementisers (e.g. dat in Dutch and Afrikaans), allowing us to understand why "wellbehaved" languages like standard Dutch, German and Afrikaans only permit V2 in the absence of an overt complementiser ${ }^{2}$ - is much more than the uncontested "classic" analysis of V2; as

\footnotetext{
${ }^{1}$ Johan Oosthuizen and I owe most grateful thanks to the following for their invaluable help on the production side of this special edition: Lauren Onraët and Franci Vosloo for their careful copy-editing work on, respectively, the English and Afrikaans contributions to this volume, and Kate Huddlestone for overseeing the final stages of the process. We also thank Jaco Grobbelaar for producing the wonderful line drawing on the cover of this special edition, and, by no means least, our contributors for their willingness to participate in this project, and for their patience while waiting for it to come to fruition.

${ }^{2}$ The following illustrates the pattern in question on the basis of standard Afrikaans:
} 
the reference point for all V2 researchers working on Germanic and beyond, it has continued to inspire new insights as ever more data has become available, and despite the very significant theoretical changes that have taken place since the late 1970s.

Tellingly, this generative side of Hans's scholarship - which, of course, extended well beyond V2 - plays only a comparatively minor role in the 373-page volume of Selected writings of Hans den Besten compiled by Ton van der Wouden in recognition of Hans's extensive work on Afrikaans (cf. van der Wouden 2012). This is because Hans den Besten is indisputably also a "key name" in Afrikaans historical linguistics, a field of study that requires empirical and historiographical knowledge and skills usually - though not necessarily correctly thought to be quite distinct from those characterising the sharpest generative linguists. In this domain, Hans again struck out on a new path, suggesting, in contrast to what he called "the South African philological school" (cf. den Besten 1986, 1987; and see also Roberge 2012 for overview discussion), that modern Afrikaans has to be viewed less as a quintessentially Germanic language, directly descended from $17^{\text {th }}$ century Dutch varieties, and more as the outcome of convergence between different varieties employed at the Cape following Dutch settlement there in the $17^{\text {th }}$ century. More specifically, den Besten's so-called "Convergence Model" (cf. i.a. Groenewald 2002, Deumert 2004 and Roberge 2012) proposes that modern Afrikaans is the product of convergence between a Cape Dutch creole, employed by nonEuropean inhabitants of the Cape colony, and the koineised extraterritorial Dutch spoken by those of European extraction. The structure of the putative Cape Dutch Creole in particular occupied much of Hans's research, with his central idea here being that the Cape Khoekhoen, "an independent nation" (den Besten 1989: 230), were its originators. According to the Convergence Model, the Khoekhoen independently developed a pidgin - Hottentots Hollands or Hottentot Dutch - which was partly modelled on the grammar of their own language, and partly reflected structural compromises between Khoekhoe and Dutch. This was subsequently taken on and elaborated by other non-Dutch-speaking populations at the Cape, with hypothetical creolisation taking place at the start of the $18^{\text {th }}$ century, the point at which the Khoekhoe moved inland. The Creole that remained at the Cape is then thought to have undergone a measure of decreolisation under the influence of the Cape Dutch spoken by those of European extraction, although further creolisation is also assumed (see den Besten 1989:

(i) Hy het die klassieke analise voorgestel.

he has the classic analysis proposed

'He proposed the classic analysis.'

(ii) Ons weet dat hy die klassieke analise voorgestel het. us know that he the classic analysis proposed have 'We know that he proposed the classic analysis.'

(iii) *Ons weet dat hy het die klassieke analise voorgestel. us know that he have the classic analysis proposed

(iv) Ons weet hy het die klassieke analise voorgestel. us know he has the classic analysis proposed 'We know he has proposed the classic analysis.'

Evidently, then, V2 verb-fronting and overtly realised complementisers are in complementary distribution, suggesting that verb-fronting targets the position occupied by the complementiser. This is den Besten's classic (V-to-C) insight. Strikingly, subsequent research has shown that this key insight holds even in cases where it at first sight appears not to, e.g. where we see V2 in the presence of an overt complementiser, as in the languages that Vikner (1995) designates "generalised" and "limited embedded V2 languages" (see Biberauer 2016 for overview discussion). 
225). Significantly, the Khoekhoe continued to use their Creole after leaving the Cape, with the result that their creolised variety came into contact with the extraterritorial Dutch spoken both in the Eastern Cape and, later, also by those who moved to the Orange River area, to which the original Cape Khoekhoe ultimately relocated. The distinctive nature of the Afrikaans spoken in this latter area - often referred to as Orange River Afrikaans (see van Rensburg 1984, 1989; Webb 1993) - is interpreted as an indication of the extent to which the Khoekhoe had developed a distinctive variety, and also of the kind of influence this kind of substrate could have on a superstrate variety. Unsurprisingly, the kind of substratist creolecentred model energetically advocated by den Besten did not find favour with everyone in Afrikaans historiographical circles. Today, a position intermediate between that of the Germanic-centric "South African philological school" and Hans's own strongly substratist Convergence Model seems most plausible (see i.a. Roberge 1994, 2002a,b,c and Deumert 2004). Crucially, however, this intermediate position would not be articulateable in anything like the precise terms that it can be today had it not been for the meticulous pioneering work of Hans den Besten. As Roberge (2012: 396) so aptly puts it:

However posterity judges Hans den Besten's views on the formation of Afrikaans, it must certainly credit him with having restored "southern Africa" to its diachronic study.

\section{Overview of the contributions to this volume}

Fittingly, in view of the above then, the contributions to this volume pick up on both of the major strands of Hans's work, with the "southern Africa" focus that he emphasised emerging particularly strongly throughout. The first two contributions focus on the Afrikaans-Dutch connection in a way which recognises the fact that it is not a foregone conclusion that modern Afrikaans and modern Dutch will always resemble each other in a straightforward way, whereafter the next three consider different Khoekhoe-related questions, with the final two offering generativism-influenced perspectives on two distinct, but both, in part, clearly unDutch components of the formal make-up of modern Afrikaans.

Taking den Besten's (2009a) desiderata for Afrikaans historical linguistics as their point of departure, Heeringa and van Huyssteen employ modern quantificational methods to measure pronunciation distances between Afrikaans and modern West Germanic varieties, with the objective being to establish which modern variety Afrikaans is closest to and, once this is known, whether this variety is close enough to modern standard Dutch for the latter to serve as the basis for the creation of the Afrikaans resources needed in human language technologies (HLT). Afrikaans is compared with three modern standard West Germanic varieties (Dutch, Frisian and German) and also with 361 dialectal varieties of Dutch, and the study identifies the South Holland dialect of Zoetermeer as Afrikaans's closest phonological relative. Comparison with standard Dutch, a resource-rich language in the HLT context, which could therefore usefully provide a starting point for the development of Afrikaans resources, reveals that the distance between Zoetermeer and standard Dutch is close enough for exploitation of existing Dutch resources to be a realistic strategy.

Beyer, in turn, reports on a project currently underway to create a very specific, but, in the first instance, non-digital resource for Afrikaans speakers, namely a concise monofunctional DutchAfrikaans dictionary, aimed at students and those more generally who find themselves having to 
read Dutch texts without necessarily having been exposed to Dutch in any systematic way. This study clearly illustrates the value of making linguistically informed decisions about lemma prioritisation in constructing dictionaries, where the question of which entries should be included is necessarily always a pressing one. More specifically, it shows that the lemma-types that users are most likely to want to look up are (i) non-cognate forms (i.e. where the Dutch word is not historically related to its Afrikaans counterpart, as is the case with verkeersdrempel referring to 'speed bumps' where Afrikaans uses spoedwalletjie or spoedhobbel), with (ii) irregular and then (iii) regular verbs next, and (iv) cognates reflecting a form-change (e.g. pad ('frog') which is padda in Afrikaans), (v) partial cognates (e.g. robot, which does not mean quite the same thing in Afrikaans and Dutch), and (vi) absolute cognates (where the two words are in fact identical in form and meaning) bringing up the rear. Among other things, then, this contribution highlights respects in which the Afrikaans lexicon has and has not remained similar - either through stasis or through undergoing parallel changes - to that of its Dutch relative.

Conradie's focus is once again on lexical items that occur in both Afrikaans and Dutch, namely modal particles. These notoriously complex little words instantiate a lexical type that Hans den Besten also had a strong and lively interest in; consider, for example, his work on challenging "little words" like possessive se (den Besten 2004), relative wat (den Besten 1996, 1999), Afrikaans's peculiar demonstratives (den Besten 2009b), clause-final nie (den Besten 1986), and differential and indirect-object-marking vir (den Besten 2000). Conradie's objective here is to probe the nature of the contribution that Khoekhoe speakers might have made to modern Afrikaans's range of modal particles, not all of which derive from Dutch. Consider hoeka and kamma, which are no longer so generally used, but which uncontroversially derive from Khoekhoe, and also particles like mos, darem, glo, and rêrig, which are etymologically derivable from Dutch, but employed in evidential-type ways that mirror the use of hoeka and kamma and depart from their core Dutch meanings. Conradie's corpus-based investigation of the particle usage of speakers of Khoekhoe origin, Cape Afrikaans speakers and speakers of standard Afrikaans suggests that it may indeed have been the case that the Khoekhoe group played an innovative role in instigating and promoting the typically Afrikaans uses to which modal particles are put - a conclusion Hans would no doubt have found pleasing!

Haacke's contribution also has a Khoekhoe focus, though his concern reverses the directionality that has been the most common in Afrikaans historiographical studies by considering loans from (Cape) Dutch and Afrikaans into a specific Khoekhoe language, Khoekhoegowab, which is spoken in Namibia. Basing himself on the 2002 Khoekhoegowab dictionary of Haacke and Eiseb, Haacke identifies approximately 300 loans from either Dutch or Afrikaans, which he then proceeds to discuss according to type. Intriguingly, a very wide range of vocabulary turns out to have been borrowed, including kinship terms like ome.b meaning 'elder maternal uncle', and forms like kriba (< Afrikaans kruiwa - 'wheelbarrow'), aili (< Dutch $i j l /$ Afrikaans $y l$ - 'rave/suffer from delirium') and muru.b (< Afrikaans moer 'coffee grounds'). Some forms have also been combined with native Khoe-forms to create hybrid lexical items like forkhō.s (< Afrikaans voorskoot - 'apron' and Khoe khō.s - 'hide, leather') and lantern!amlae.s (< Afrikaans lantern - 'lantern' and Khoe !amlae.s - 'lamp'). Further, calques like mîixuu.-i ('say' + 'thing' from Afrikaans sê-goed, literally: 'say-things') and lawałai.b ('red' + 'foot' from Afrikaans pienkvoet, literally: 'pink-foot') can also be identified. Particularly interestingly from the perspective of den Besten's hypothesis about the influence of Khoekhoe on Afrikaans grammar, Haacke also offers discussion of a number of respects in which Khoekhoegowab lexical structure seems to mirror patterns found in 
modern-day Afrikaans. Notable among these are the many compound (i.e. noun- and adposition-incorporating) verb forms that seem in part to mirror Afrikaans's West Germanic particle verbs, and "double verb" forms that may have given rise to Afrikaans innovations like bly staan ('remain stand'), which, as deVos (2006) shows, may undergo so-called "quirky Verb Second" (Hoekom bly staan julle net? literally: why remain stand you.PL just, i.e. 'Why are you just staying put?').

The final Khoekhoe-oriented contribution is van Rensburg's, with the focus here being the impact of the Khoi on so-called Oosgrensafrikaans, or the Afrikaans spoken at the eastern boundaries of the Cape Colony from 1700 onwards (van Rensburg 1983). The author's objective is to show that the circumstances that held in the interior between 1700 and 1840 were in fact much more favourable to Khoekhoe influence on Afrikaans than those that held in the Cape during the first 50 years following the initial establishment of a refreshment station. Van Rensburg's central thesis, then, picks up on den Besten's argument for a twostage Khoekhoe influence on the formation of Afrikaans (see above), making the case for the, to date, mostly insufficiently recognised importance of the second, non-Cape-based stage, and, particularly, the contribution of developments on the Eastern frontier. As examples of modern-day properties that initially became most strongly established in Oosgrensafrikaans, van Rensburg cites distinctive phenomena like the nominative (subject) use of originally accusative (object) ons ('us'), and also the use of hom ('him'), ek ('I'), and relative wat in place of die, the demonstratives hierdie ('this') and daardie ('that'), the se-possessive, and clause-final nie. Like the other papers in the "Khoekhoe section" of this volume, van Rensburg's paper, then, offers an excellent demonstration of the kind of "southern African" thinking that Hans den Besten's work on Afrikaans historiography has produced.

Two broadly generatively oriented papers, both focusing in part on "little words", conclude the volume. The first, Oosthuizen's chapter, has a primarily descriptive objective, aiming to set out, in minimally technical terms, the range of reflexive structures permitted in modern Afrikaans. These differ from those found in Dutch not only by virtue of the absence in Afrikaans of a morphologically simplex zich ('self')-type reflexive, but also by virtue of the various ways in which Afrikaans employs personal pronouns to express reflexive meanings. The latter option is, of course, available in Dutch, but Afrikaans has developed a system that clearly differs, and, moreover, does so systematically, from what is found in Dutch. Oosthuizen's contribution provides a systematic overview of the different factors determining when complex (-self-containing) and simple pronominal forms are required. Further, he highlights the possibility of reflexively used possessive pronouns, which, like their better studied personal-pronoun counterparts, appear both in optionally and obligatorily reflexive contexts. And the study also does not restrict itself to the anaphor component in Afrikaans reflexive structures; the matter of which elements may serve as antecedents is also considered, with the conclusion that emerges being that, in Afrikaans, it is not just subjects - the usual suspect in this context - but also direct, indirect and prepositional objects that may antecede reflexives. With such a thorough description in place, the scene is set, as Oosthuizen also notes in his conclusion, for a rigorous theoretical analysis. This, appropriately enough, he himself provides in his doctoral dissertation that Hans den Besten formally supervised until his premature passing (Oosthuizen 2013).

The final paper, my own, is concerned with Afrikaans's much-discussed clause-final nie. The paper attempts to demonstrate just how peculiar the modern Afrikaans negation system is, and 
what a central role clause-final nie has played in creating the conditions for the rise of this strangeness. Following Roberge (2000), I argue that final nie has its origins as an emphatic spoken-language resumptive discourse particle (Dit kannie waar wees, nee! - literally: it cannot true be, no, i.e. 'It can't be true, no!'), which acquirers incorporated into their grammars in such a way that a Negative Concord system very different from that in familiar Western European languages (e.g. French) resulted. ${ }^{3}$ Strikingly, negative systems featuring bipartite negation with clause-final negators do occur outside of Europe, notably in Central Africa (Bell 2004, Dryer 2009, deVos and van der Auwera 2013), and it would seem that the modern Afrikaans negation system shares properties with these non-European systems. The reasons for this can clearly not be either genetic relatedness or contact, raising the intriguing possibility that the still vastly under-researched question of how humans "go beyond the input" in acquiring language, creating structure that was not there before, may be relevant here. Crucially, however, an overall negation system exhibiting exactly the properties of standard Afrikaans has not so far been shown to exist anywhere else in the world (Biberauer and Zeijlstra 2012). Consideration of what this kind of system entails from an acquisition perspective suggests why this may be so: the combination of standard Afrikaans's ultimately prescriptively imposed "double nie" Negative Concord system - where final nie consistently fails to add a further negation to the negative meaning(s) already introduced by other negatively-marked elements - with the "original" West Germanic non-Negative Concord system - where every negation element other than final nie must be interpreted as contributing a negative meaning - can be shown to be one that cannot be acquired without prescriptive input. ${ }^{4}$ If this reasoning is correct, then, the negation component of standard Afrikaans does not instantiate a natural system - a conclusion which, I imagine, Hans den Besten, with his intense interest in non-standard Afrikaans varieties and the ways in which non-European speakers and their languages shaped modern Afrikaans, would rather have enjoyed.

\footnotetext{
${ }^{3}$ That the clause-final negation patterns den Besten $(1978,1985,1986)$ observed in Khoekhoe may have had a convergent role in establishing the final polarity-reinforcing element that Roberge identifies as the source of Afrikaans nie $_{2}$ is, of course, not ruled out. In fact, detailed consideration of this possibility is a desideratum for further research on Afrikaans negation.

${ }^{4}$ By contrast, a more consistently Negative Concord system such as that which is typically heard in modern spoken Afrikaans can be shown to be readily acquirable without prescriptive input. Consider the following actually attested examples:
}

(i) Niemand het niks gedoen nie. no-one have nothing done NIE 'No-one did anything.', i.e. a Negative Concord reading. Contrast standard Afrikaans 'No-one did nothing', i.e. everyone did something.

(ii) Dit was nog nooit nêrens die geval gewees nie. that was still never nowhere the case been NIE

'That has never been the case anywhere.' Contrast standard Afrikaans 'That has NEVER been the case nowhere' or 'That has never been the case NOWHERE', i.e. it was (always) the case somewhere (necessarily some kind of emphatic interpretation). 


\section{References}

Bell, A. 2004. Bipartite Negation and the Fine Structure of the Negative Phrase. Doctoral dissertation, Cornell University.

Den Besten, H. 1977/1983. On the interaction of root transformations and lexical deletive rules. In W. Abraham (Ed.) On the formal syntax of the West Germania. Amsterdam: Benjamins. pp. 47-131.

Den Besten, H. 1978. Cases of possible syntactic interference in the development of Afrikaans. In P. Muysken (Ed.) Amsterdam Creole Studies II. Amsterdam: University of Amsterdam. pp. 5-56.

Den Besten, H. 1985. Die doppelte Negation im Afrikaans und ihre Herkunft. In N. Boretzky, W. Enninger and T. Stolz (Eds.) Akten des 1. Essener Kolloquiums über "Kreolsprachen und Sprachkontakte”. Bochum: Studienverlag. pp. 9-42.

Den Besten, H. 1986. Double negation and the genesis of Afrikaans. In P. Muysken and N. Smith (Eds.) Substrata versus universals in creole genesis. Amsterdam: Benjamins. pp. 185-230. (Chapter 12 of van der Wouden (Ed.))

Den Besten, H. 1987. Het Afrikaans: Mag het ietsje meer Zuid-Afrika zijn? Onze Taal 56: 24-25.

Den Besten, H. 1989. From Khoekhoe to Foreigner Talk via Hottentot Dutch to Afrikaans: The creation of a novel grammar. In M. Pütz and R. Dirven (Eds.) Wheels within wheels. Papers of the Duisburg Symposium on Pidgin and Creole Languages. Frankfurt: Peter Lang. (Chapter 13 of van der Wouden (ed.))

Den Besten, H. 1996. Relatief wat en de West-Germaanse relativatiesystemen. In H. den Besten, J. Goossens, F. Ponelis and P. van Reenen (Eds.) Afrikaans en variëteiten van het Nederlands. Amsterdam: P.J. Meertens-Instituut. pp. 12-24. (Taal en Tongval 9, 12-34, and, in translated form, Chapter 4 of van der Wouden (Ed.))

Den Besten, H. 1998. What a little word can do for you: wat in Afrikaans possessive relatives. In S. Barbiers, J. Rooryck and J. van de Weijer (Eds.) Small words in the big picture. Squibs for Hans Bennis. Leiden: Holland Institute of Generative Linguistics. pp. 13-21. (Chapter 3 of van der Wouden (Ed.))

Den Besten, H. 2000. The slaves' languages in the Dutch Cape colony and Afrikaans vir. Linguistics 38(5): 949-971. (Chapter 15 of van der Wouden (Ed.))

Den Besten, H. 2004. The origins of the Afrikaans pre-nominal possessive system(s). Paper presented at the Curaçao Creole Conference. (Chapter 1 of van der Wouden (Ed.))

Den Besten, H. 2009a. Desiderata voor de historische taalkunde van het Afrikaans. In H. den Besten, F. Hinskens and J. Koch (Eds.) Afrikaans. Een drieluik. Amsterdam: Stichting Neerlandistiek. pp. 234-252. (Chapter 17 of van der Wouden (Ed.)) 
Den Besten, H. 2009b. Demonstratives in Afrikaans and Cape Dutch Pidgin: A first attempt. In E. Aboh and N. Smith (Eds.) Complex processes in new languages. Amsterdam: Benjamins. pp. 201-219. (Chapter 5 of van der Wouden (Ed.))

Biberauer, T. 2016. Afrikaans V2 and its implications for our understanding of V2 parameterisation. Paper to be presented at the Rethinking Verb Second Workshop (Cambridge).

Biberauer, T. and H. Zeijlstra. 2012. Negative Concord in Afrikaans: Filling a typological gap. Journal of Semantics 29(3): 345-371.

Deumert, A. 2004. Language standardization and language change. The dynamics of Cape Dutch. Amsterdam: Benjamins.

DeVos, M. and J. van der Auwera. 2013. Jespersen cycles in Bantu: Double and triple negation. Journal of African Languages and Linguistics 34: 205-274.

Dryer, M. 2009. Verb-Object-Negative order in Central Africa. In N. Cyffer, E. Ebermann and G. Ziegelmeyer (Eds). Negation patterns in West Africa. Amsterdam: Benjamins. pp. 307-362.

Groenewald, G. 2002. Slawe, Khoekhoen en Nederlandse Pidgins aan die Kaap, ca. 15901720: ' $n$ Kritiese Ondersoek na die Sosiohistoriese Grondslae van die Konvergensieteorie oor die Ontstaan van Afrikaans. MA dissertation, University of Cape Town.

Haacke, W. and E, Eiseb. 2002. A Khoekhoegowab dictionary with an EnglishKhoekhoegowab index. Windhoek: Gamsberg-Macmillan.

Holmberg, A. 2015. Verb Second. In T. Kiss and A. Alexiadou (Eds.) Theory and analysis. An international handbook. Berlin: Mouton de Gruyter. pp. 242-283.

Oosthuizen, J. 2013. Obligatory Reflexivity in Afrikaans. A Minimalist Approach. Doctoral dissertation, University of Stellenbosch.

Van Rensburg, M.C.J. 1983. Nie-standaardvorme, variasiepatrone en Afrikaans van die vorige eeu. In G. Claasen and M.C.J. van Rensburg (Eds.) Taalverskeidenheid. 'n Blik op die spektrum van taalvariasie in Afrikaans. Pretoria: Academica. pp. 134-161.

Van Rensburg, M.C.J. 1984. Finale verslag van 'n ondersoek na "Die Afrikaans van die Griekwas van die tagtigerjare" onderneem met finansiële steun van die RGN (2 parts). Bloemfontein: University of the Orange Free State.

Van Rensburg, M.C.J. 1989. Soorte Afrikaans. In T.J.R. Botha (Ed.) Inleiding tot die Afrikaanse taalkunde. Pretoria: Academica. pp. 436-467.

Roberge, P. 1994. The formation of Afrikaans. Stellenbosch Papers in Linguistics Plus 23: 1-110.

Roberge, P. 2000. Etymological opacity, hybridization, and the Afrikaans brace negation. American Journal of Germanic Linguistics and Literatures 12(1): 101-176. 
Roberge, P. 2002a. Afrikaans. In A. Deumert and W. Vandenbussche (Eds.) Germanic standardizations. Past to present. Amsterdam: Benjamins. pp. 15-40.

Roberge, P. 2002b. Afrikaans: Considering origins. In R. Mesthrie (Ed.) Language in South Africa. Cambridge: Cambridge University Press. pp. 79-103.

Roberge, P. 2002c. Convergence and the formation of Afrikaans. Journal of Germanic Linguistics 14(1): 57-93.

Roberge, P. 2012. Afrikaans. "Might it be a little more "South Africa'?". In T. van der Wouden (Ed.) The roots of Afrikaans. Selected writings of Hans den Besten. Amsterdam: Benjamins. pp. 389-397.

Vikner, S. 1995. Verb movement and expletive subjects in the Germanic languages. New York: Oxford University Press.

DeVos, M. 2006. Quirky verb-second in Afrikaans: Complex predicates and head movement. In J. Hartmann and L. Molnárfi (Eds.) Comparative studies in Germanic syntax: From A(frikaans) to Z(urich German). Amsterdam: Benjamins. pp. 89-114.

Webb, V. 1993. Die herkoms van Oranjerivierafrikaans. Linguistica. Festschrift E.B. van Wyk. Pretoria: van Schaik. pp. 161-171.

Van der Wouden, T. 2012. The roots of Afrikaans. Selected writings of Hans den Besten. Amsterdam: Benjamins. 